\title{
Analisis Limbah Medis Layanan Kesehatan Gigi Mandiri dan Potensi Pencemarannya di Kota Pekanbaru
}

\author{
Oktavia Dewi $^{1}$, Sukendi ${ }^{2}$, Yusni Ikhwan Siregar ${ }^{2}$, Elda Nazriati ${ }^{3}$ \\ ${ }^{1}$ STIKes Hang Tuah Pekanbaru Jalan Mustafa Sari No 05 Pekanbaru \\ ${ }^{2}$ Program Studi Magister Ilmu Lingkungan Program Pascasarjana Universitas Riau Jalan Pattimura No.09 \\ Gedung.I Gobah Pekanbaru, Telp. 0761-23742 \\ ${ }^{3}$ Fakultas Kedokteran Universitas Riau Jalan Diponegoro No. 01 Pekanbaru Riau
}

\begin{abstract}
Healthcare development contributing positive outcome on public health status, but on the other side, medical waste existence become a troublesome as long as increased medical healthcare quantity particularly private dental healthcare. The amount of improperly managed medical wastes become accumulated and causing widespread pollution. The roblem of this study is improperly managed medical waste getting more increased causing widespread pollution. Even though 15-25\% of this contamination were categorized as hazardous waste, the risk is much greater. The purpose of this study was to analyze the number and types of private healthcare medical waste and its potential pollution. This study used descriptive qualitative with interviews and observations after conducting a survey of calculating the number and identification of medical waste types produced by private dental healthcare in Pekanbaru. The results showed 69\% of infectious, 27\% toxic, and 4\% radioactive wastes. The presence of this medical waste has the potential to polluting water and soil environment, triggering health problems for health workers and high risk communities, and disrupting social and economic aspects of residents at nearby waste disposal. It is recommended that private dental healthcare to reduce generated medical wastes and to use safe and eco-friendly materials and tools for dental and oral care.
\end{abstract}

Key Words: Private Dental Healthcare Medical Wastes, Infectious Medical Wastes, Toxic Wastes, Radioactive Wastes, Pollution

Perkembangan ilmu pengetahuan dan teknologi mengantarkan manusia pada situasi yang semakin menguntungkan. Namun perkembangan itu memiliki dampak yang berpotensi menjadi masalah lingkungan, masalah individu dimasa yang akan datang. Berbagai macam sarana kesehatan dalam menjalankan kegiatannya, seperti rumah sakit, balai pengobatan, laboratorium, praktek layanan kesehaan mandiri, akan menghasilkan limbah yang dikenal dengan istilah limbah medis. Praktek dokter gigi juga termasuk salah satu sarana pelayanan kesehatan yang juga menghasilkan limbah medis. Jumlah limbah medis terus meningkat seiring bertambahnya jumlah sarana layanan kesehatan, begitu juga dengan limbah sarana layanan kesehatan gigi. Berdasarkan penelitian di Mumbai, rata-rata limbah klinik gigi yang dihasilkan sekitar 0,5$1,0 \mathrm{~kg}$ per hari. Setiap tahun praktek dokter gigi di dunia menghasilkan 4,8 juta lead foils, 2,8 juta liter fixer $x$ ray beracun, 3,7 ton limbah mercuri, 1,7 juta bahan sterilisasi, 680 juta chair barrier, ligh handle covers dan patient bibs (Baghele et al., 2013).

Limbah yang meningkat harus diimbangi oleh perilaku pengelolaan limbah yang benar dan sesuai aturan, yaitu perilaku yang tidak menyebabkan pencemaran. Menurut UU RI No.23 tahun 1997 pencemaran adalah masuknya atau dimasukkannya makhluk hidup, zat,energi, dan/atau komponen lain ke dalam lingkungan hidup oleh kegiatan manusia sehingga kualitasnya turun sampai ke tingkat tertentu yang menyebabkan lingkungan hidup tidak dapat berfungsi sesuaidengan peruntukannya. Berdasarkan hasil laporan Chandigarh et al (2013) bahwa 26\% dari dokter gigi membuang sisa potongan tubuh (gigi dan jaringan yang diekstraksi), $44 \%$ membuang amalgam dan $12 \%$ membuang kawat gigi langsung ke tempat sampah umum. Limbah medis yang tidak diolah dengan benar dapat menyebabkan pencemaran pada air, udara dan 
tanah sehingga dapat mengganggu kesehatan dan kehidupan sosial. Suatu studi menunjukkan bahwa air limbah dari layanan kesehatan gigi biasanya mengandung konsentrasi tinggi dari logam seperti merkuri, perak, tembaga, timah dan seng. Sumber logam ini termasuk bahan sisa hasil pembuangan tambalan amalgam dan pembuangan sisa pencucian $x$-ray fixer (perak) dibuang ke saluran pembuangan umum atau septik tank. Hasil pemantauan beberapa peneliti di laut mengidentifikasi merkuri, tembaga dan seng sebagai kontaminan utama dalam sedimen laut. Merkuri, khususnya, dikenal menumpuk dalam jaringan ikan, tanaman dan mamalia dan "biokonsentrat" dalam rantai makanan (Goya et al., 2016). Tujuan dari penelitian ini adalah untuk melihat karakteristik limbah medis berdasarkan jenis dan jumlah limbah medis layanan kesehatan gigi di kota Pekanbaru dan menganalisa potensi dampak pencemarannya terhadap lingkungan.

\section{BAHAN DAN METODE}

Penelitian ini dilakukan pendekatan secara dua tahap. Pertama; menggunakan pendekatan secara kuantitatif deskriptif untuk mengetahui jumlah limbah medis yang dihasilkan layanan kesehatan gigi mandiri dengan jumlah sampel sebanyak 14 tempat praktek dokter gigi selama 20 hari kerja. Kedua; menggunakan pendekatan kualitatif analitik untuk menganalisa potensi pencemaran pada limbah medis layanan kesehatan gigi mandiri dengan melakukan wawancara mendalam dan observasi terhadap beberapa orang informan.

Untuk mendapatkan data potensi dampak limbah medis layanan kesehatan gigi terhadap lingkungan, sosial ekonomi, dan strategi pengelolaan limbah maka ditentukan beberapa informan yang dapat memberikan informasi yang mempunyai pengetahuan, pengalaman, keahlian, kedudukan dan jabatan yang sesuai dengan bidang yang akan dianalisis. Informan terdiri dari 1 orang kepala dinas kesehatan kota pekanbaru, 1 orang kasi kesehatan lingkungan dinas kesehatan kota pekanbaru, 1 orang ketua pdgi kota pekanbaru, 4 orang dokter gigi, 2 orang perawat gigi, 2 orang pemulung di TPS dan TPA kota Pekanbaru, petugas kebersihan dan masyarakat sekitar TPS.

\section{HASIL}

\section{Potensi Dampak Limbah Medis Layanan Kesehatan Gigi terhadap Lingkungan.}

Berdasarkan hasil penelitian terhadap 14 tempat praktek mandiri dokter gigi di Kota Pekanbaru, diketahui bahwa rerata limbah yang berpotensi infeksius per hari adalah $3,2 \mathrm{~kg}$, limbah medis berpotensi toksik adalah $1,2 \mathrm{~kg}$ perhari dan limbah medis berpotensi radioaktif adalah $0,18 \mathrm{~kg}$ perhari. Limbah medis gigi yang berbahan zat radioaktif yang dihasilkan berbentuk dental amalgam. Berdasarkan persentasenya adalah limbah infeksius 69\%, limbah bahan toksik $27 \%$ dan limbah bahan radioaktif $4 \%$.

Berdasarkan penghitungan hasil identifikasi limbah yang dilakukan maka pada umumnya dokter gigi layanan kesehatan mandiri di kota Pekanbaru menghasilkan limbah kain kassa, kapas dan sarung tangan yang terkontaminasi air ludah dan darah setiap hari. Bahan limbah medis yang berpotensi toksik dihasilkan oleh dokter gigi setiap 3 hari, yaitu sisa gypsum, sisa cairan resin acrylic yang mengandung methyl methacrylate. Bahan limbah medis berpotensi radioaktif adalah amalgam yang mengandung mercuri dihasilkan setiap 3 sampai 8 hari sekali.

Limbah medis berbahan toxic yang dihasilkan layanan kesehatan gigi pada penelitian ini mempunyai kontribusi sebesar $27 \%$ dari seluruh limbah medis. Jenis yang sering dihasilkan adalah gypsum dan partikel akrilik. Berdasarkan hasil wawancara dengan informan perawat, dokter gigi dan petugas kebersihan menyatakan membuang limbah gypsum dihalaman rumah sebagai bahan timbunan, merasakan sesak pada saat terhirup partikel akrilik sewaktu membuat gigi palsu, mengalami terkelupasnya kuku tangan akibat berkontak cairan akrilik yang mengandung zat methylmethacrilate dan merasa gatal gatal ketika menyentuh cairan dari limbah di tempat menampungan sampah. Hasil wawancara sebagai berikut :

" "... Membuang sisa gypsum gigi dihalaman depan rumah sebagai bahan timbunan "Pernah mengalami kehilangan kuku jari tangan karena terkontaminasi cairan akrilic (methymethacrilate) pada waktu pembuatan prothesa" 
"..Mengalami sesak dan berdahak yg menggumpal diduga karena terhirup partikel akrilic"

" "Kena cairan sampah....sering gatal gatal tangannya..."

\section{Potensi Dampak Limbah Medis Layanan Kesehatan Gigi terhadap Sosial Ekonomi}

Berdasarkan hasil wawancara dengan beberapa informan didapat informasi bahwa sebagian besar limbah infeksius dibuang di tempat sampah bercampur dengan sampah lainnya sehingga dapat mencemari limbah non infeksius dan dapat berpotensi menimbulkan berbagai keluhan kesehatan seperti hasil wawancara berikut :

"... Pada umumnya jarum suntik, kapas bekas darah, sarung tangan sekali pakai di buang di tong sampah umum bercampur dengan sampah lainnya.."

"... pernah tertusuk jarum suntik hanya luka dan tidak ada keluhan lainnya ..."

"..pernah tertusuk jarum dan benda tajam"

"..masyarakat sekitar pernah melihat jarum suntik bekas, kapas berdarah yang dikerumuni lalat dan dibongkar binatang “"

Potensi dampak limbah medis layanan kesehatan gigi pada masyarakat yang terlibat dengan sampah medis ini sebagian ada yang menguntungkan karena merupakan mata pencaharian dan menambah pendapatan seperti pendapat pemulung di TPS bahwa mereka bisa mendapatkan uang sampai Rp 36.000 perharinya dan sebagian ada yang merugikan karena kehilangan pendapatan harian akibat tidak bisa melakukan pekerjaan karena sakit. Begitu juga dengan yang dialami masyarakat setempat yang berjualan, mereka bisa menjadi rugi karena dagangannya tidak laku karena banyaknya lalat dan bau disekitar tumpukan sampah. Hal ini dapat dibuktikan dengan pernyataan beberapa informan sebagai berikut :

"... 4 hari saya tidak masuk kerja bu..." ....".. nt saya ga bisa kerja..anak istri saya ga makan... mau makan pake apa... apa apa sekarang mahal lho bu. Klu pemulung sih bisa jual ..."

".........klu dapat jarum... dipatahkan ujungnya trus dibuang......klu botol obat, adalah beberapa... dijual aja "..........hasil pulungan untuk dijual...didepan tps ini...diseberang jalan.....rp 1300/kilo......."... klu penuh 20 kilo kali 1300 rupiah adalah 36 rb.....kadang separonya..."

".........selain tidak bagus dilihat juga menimbulkan bau. Apalagi bagi saya yg jualan makanan.....banyak lalat disekitar sini.." ........jualan saya pun juga kurang lakunya karena orang tidak mau mampir karena tidak tahan baunya. Lumayan rugi juga saya..."

\section{PEMBAHASAN}

\section{Potensi Dampak Limbah Medis Layanan Kesehatan Gigi terhadap Lingkungan.}

Jumlah rerata limbah medis layanan kesehatan gigi mandiri di kota Pekanbaru masih berada dibawah rerata limbah yang dihasilkan di Mumbai India yaitu sebanyak $0,5-1,0 \mathrm{~kg}$ perhari (Baghele, 2013), tetapi masih lebih tinggi dibandingkan dengan penelitian Wulandari (2011) yang menyatakan rerata jumlah limbah medis layanan kesehatan gigi berizin di Bandung sebanyak 142,77 gram tiap praktek dokter gigi setiap hari. Hal ini berarti dokter gigi yang melakukan layanan kesehatan mandiri masih menghasilkan limbah medis dengan jumlah yang cukup banyak. Berdasarkan penelitian Adegdiba (2010) limbah infeksius dapat menyebabkan penyakit akibat infeksi silang yang ditularkan oleh hewan yang berkontak dengan limbah seperti lalat, tikus seperti diare dan pes serta manusia yang berkontak langsung dengan limbah infeksius seperti Hepatitis dan Human Imunodefisiensi Virus.

Dalam pembuatan gigi palsu terjadi pencampuran bahan tepung dan cair untuk menghasilkan senyawa resin. Cairan resin mengandung senyawa methylmethacrilate (MME) yang mempunyai efek yang berbahaya jika terhirup dan berkontak langsung dengan kulit. Berdasarkan penelitian Haroon R (2015) yang melibatkan mengekspos tikus ke uap MME menunjukkan bahwa ada manifestasi histologis yang terjadi seperti edema, emfisema, dan bahkan kolapsnya paru-paru. Oleh karena itu, harus ditekankan bahwa petugas kesehatan gigi yang memanipulasi resin akrilik harus bekerja di lingkungan yang benar-benar berventilasi sehingga efek berbahaya termasuk dyspnea, batuk, dan pemicu asma dapat diminimalkan dan dihindari secara ideal. MME dapat juga menembus kulit dan juga disarankan 
agar resin selama pencampuran tidak dipegang dengan tangan kosong karena efek neurotoksik langsung dapat disebabkan. Fungsi saraf myelinated telah terbukti terpengaruh jika MME diserap langsung melalui kulit dan dapat menyebabkan neuropati.

Gypsum kedokteran gigi atau dikenal dengan Plaster of paris merupakan bahan yang paling banyak digunakan dalam proses pencetakan gigi. Berdasarkan hasil penelitian penggunaan gypsum pada layanan kesehatan gigi di Kota Pekanbaru digunakan 3 hari sekali dan menurut Koolivand,(2013) jumlah gymsum yang dihasilkan 3,5 kg/hari. Berdasarkan wawancara pada dokter gigi dan perawat gigi, limbah gypsum dibuang ke tong sampah biasa bahkan dibuang ke halaman atau jalan sebagai bahan timbunan karena bentuk fisiknya gypsum seperti batu. Menurut Rebeca A ( 2016 ) sesuai dengan Peraturan Izin Lingkungan 2010 (Inggris dan Wales), semua gypsum dilarang dibuang ditempat pembuangan sampah umum dan harus dilakukan pemisahan dengan sampah lainnya. Hal ini disebabkan karena limbah gypsum akan menghasilkan gas hidrogen sulfida (H2S) dari aksi mikroba yang menyebabkan bau busuk dan dengan sinar matahari dapat menimbulkan gas $\mathrm{SO} 2$ yang mudah terbakar sehingga terjadi pencemaran lingkungan. Pencemaran udara yang mengandung gas SO2 dapat menyebabkan terjadinya iritasi tenggorokan pada konsentrasi lebih dari 5 ppm diudara. Bahkan untuk penderita yang mempunyai gangguan pada system pernafasan, kardiovaskular, dan lanjut usia, paparan 0,2 ppm sudah menyebabkan iritasi tenggorokan. Selain dampak terhadap kesehatan manusia, gas SO2 juga merusak tanaman dan bangunan akibat pembentukan hujan asam dari reaksi $1 / 2 \mathrm{O} 2+$ $\mathrm{SO} 2+\mathrm{H} 2 \mathrm{O}$ menjadi $\mathrm{H} 2 \mathrm{SO} 4$ (Abdelfatah 2008).

Berdasarkan penelitian Margotz (2007) dokter gigi di Kanada menghasilkan sekitar 781 $\mathrm{kg}$ limbah amalgam setiap tahun. Menurut penelitian Nadia (2016) di Lahore Pakistan dilaporkan bahwa air limbah gigi dapat menghasilkan merkuri hingga 4,5 gram / hari / dokter gigi dan sekitar 100-200 g dari merkuri per tahun. Saat ini, telah diperkirakan bahwa dokter gigi berkontribusi 3\% menghasilkan merkuri yang terkandung dari bahan tambalan gigi yang dikenal dengan amalgam. Sebanyak
$70 \%$ dari total merkuri yang dihasilkan oleh layanan kesehatan gigi di buang sebagai limbah. Jika praktisi yang secara rutin melakukan pengolahan limbah restorasi amalgam, jumlah limbah yang dilepaskan ke lingkungan akan dikurangi sekitar $27 \%$.

Bahan tambalan amalgam terdiri dari 50\% merkuri dan logam lain seperti perak, timah dan tembaga. Setiap kapsul amalgam mengandung 6 mg merkuri dan 6 mg campuran logam lainnya. Tergantung dari kondisi besarnya lobang gigi, tambalan dapat menggunakan beberapa atau satu bahkan setengah kapsul amalgam.

Berdasarkan penelitian Maria (2014) kadar merkuri (evaporation rate) pada saat pengadukan lebih tinggi dibandingkan pada saat pengerasan. Jadi pada saat aplikasi bahan tambalan amalgam dokter gigi jauh lebih beresiko terpapar merkuri dibandingkan pasien, karena fase yang paling berbahaya adalah fase uap apalagi jika pekerjaan dilakukan diruangan kecil dan tertutup dan tanpa masker. Pada saat pembongkaran tambalan amalgam, serbuk halus tambalan sebagian tertelan oleh pasien dan sebagian terhirup oleh dokter gigi. Berdasarkan laporan dari Bali Focus Fondation bahwa konsentrasi uap merkuri di beberapa klinik gigi di rumah sakit di Bali melebihi nilai ambang batas aman yang ditetapkan WHO (Sonia ,2016)

Merkuri yang terhisap dapat lewat udara berdampak akut atau terakumulasi dan terbawa ke organ-organ tubuh lainnya, menyebabkan bronkitis, hingga rusaknya paru-paru. Pada keracunan merkuri tingkat awal, pasien merasa mulutnya kebal sehingga tidak peka terhadap rasa dan suhu, hidung tidak peka bau, mudah lelah, dan sering sakit kepala. Jika terjadi akumulasi yang lebih dapat berakibat pada degenerasi sel-sel saraf di otak kecil yang menguasai koordinasi saraf, gangguan pada luas pandang, degenerasi pada sarung selaput saraf dan bagian dari otak kecil. Berdasarkan penelitian yang dilakukan di Amerika dinyatakan bahwa dokter gigi 7,6 kali beresiko mengalami masalah neurologis dan perawat beresiko $63 \%$ tidak hamil akibat terpapar oleh merkuri yang ada pada amalgam (Ismawati $\mathrm{Y}$ dalam Sonia 2016)

Merkuri dalam bentuk logam tidak begitu berbahaya, karena hanya $15 \%$ yang bisa terserap tubuh manusia. Tetapi begitu terpapar ke alam, dalam kondisi tertentu dapat bereaksi dengan 
metana yang berasal dari dekomposisi senyawa organik membentuk metil merkuri yang bersifat toksis. Dalam bentuk metil merkuri, sebagian besar akan berakumulasi di otak. Karena penyerapannya besar, dalam waktu singkat bisa menyebabkan berbagai gangguan. Mulai dari rusaknya keseimbangan tubuh, tidak bisa berkonsentrasi dan tuli.(Sonia.2016).

Berdasarkan hasil penelitian Adedigba (2010) yang dilakukan di rumah sakit gigi dan mulut di nigeria didapatkan kandungan merkuri dalam tanah berjarak 0 sampai 0,15 meter sebanyak $250 \mathrm{ppm}$ jauh melebihi standar baku berdasarkan FEPA (standards set for drinkable water and agricultural soil ) yaitu 0,05 ppm. Menurut penelitian Irhami (2017), kadar merkuri pada air lindi TPA di Kota Banda Aceh sebesar 0,00463 ppm, hampir melewati batas ambang berdasarkan Peraturan Menteri Lingkungan Hidup dan Kehutanan Republik Indonesia nomor p.59/menlhk/setjen/kum.1/7/2016 tentang baku mutu lindi bagi usaha dan/atau kegiatan bahwa standar baku mutu merkuri pada air lindi di TPA kurang dari $0,005 \mathrm{mg} / \mathrm{l}$

Bentuk masalah merkuri yang sering terjadi dalam populasi adalah terdapatnya senyawa metil merkuri dari ikan yang tercemar, merkuri inorganik dari makanan, dan merkuri murni dari dental amalgam restoration. Jika distribusi metil merkuri di dalam tubuh bercampur dengan unsur yang lebih kompleks maka dapat mengganggu jaringan otak dikarenakan unsur tersebut masuk ke dalam darah dan bercampur dengan darah. Jika unsur merkuri kompleks masuk ke dalam jaringan otak melalui aliran darah, maka penderita akan mengalami gangguan mental dan lama kelamaan akan mati

Ada beberapa cara untuk dapat menetralisir kadar merkuri, salah satunya dengan mengembangbiakan bakteri, karena diketahui ada bakteri yang dapat bertahan hidup dalam lingkungan yang mengandung merkuri dalam jumlah tinggi. Bakteri itu adalah Pseudomonas fluorescens, Staphylococcus aureus, dan Bacillus sp. Hal ini menginspirasi ahli biologi molekuler untuk memadukan fungsi gen beberapa bakteri hingga menghasilkan strain unggul untuk mengatasi pencemaran merkuri secara cepat dan efektif ( Triadi, 2011).

\section{Potensi Dampak Limbah Medis Layanan Kesehatan Gigi terhadap Sosial Ekonomi}

Potensi dampak limbah medis layanan kesehatan gigi pada masyarakat yang terlibat dengan sampah medis ini sebagian ada yang menguntungkan karena merupakan mata pencaharian dan menambah dan sebagian ada yang merugikan karena kehilangan pendapatan harian akibat tidak bisa melakukan pekerjaan karena sakit.

Resiko terganggunya kesehatan pemulung, istri dan anak pemulung sangat tinggi. Pada umumnya mereka seringkali dihinggapi penyakit perut, sakit kepala, sesak napas dan infeksi saluran pernapasan akut (ISPA). Penyakit perut dan sakit kepala sudah dirasakan sebagai penyakit menahun. Sakit perut yang diderita diduga disebabkan cemaran bakteri sampah pada makanan dan air minum yang diduga disebabkan oleh timbunan sampah yang berada di lingkungan mereka. Beberapa faktor yang menyebabkan pemulung, istri, dan anaknya pemulung seringkali mengalami gangguan kesehatan, selain tidak mencoba untuk melakukan pencegahan, pengetahuan tentang kesehatan yang rendah (Suhartono,2015)

\section{SIMPULAN}

Kesimpulan penelitian ini sebagai berikut :

1. Jumlah rerata limbah yang berpotensi infeksius per hari adalah $3,2 \mathrm{~kg}$, limbah medis berpotensi toksik adalah $1,2 \mathrm{~kg}$ perhari dan limbah medis berpotensi radioaktif adalah $0,18 \mathrm{~kg}$ perhari. Berdasarkan persentase limbah medis layanan kesehatan gigi mandiri di Kota Pekanbaru yang berpotensi infeksius sebanyak $69 \%$, toxic $27 \%$ dan bahan berbahaya $4 \%$.

2. Limbah medis layanan kesehatan gigi mempunyai potensi terjadinya pencemaran lingkungan, potensi gangguan sosial dengan menimbulkan ketidaknyamanan dan gangguan kesehatan serta potensi gangguan ekonomi dengan bertambahnya biaya yang harus dikeluarkan jika terkena dampak limbah layanan kesehaan gigi yang tidak di kelola dengan baik. 


\section{UCAPAN TERIMA KASIH}

Ucapan terima kasih penulis ucapkan kepada pihak-pihak yang telah membantu dalam terlaksananya penelitian ini.

\section{DAFTAR PUSTAKA}

Abdelfatah,2008. Environmental Implications of Recycling and Recycled Products

Baghele, O., Baghele, M., Deshpande, A., Deshpande, J. and Phadke, S. 2013 'A simplified model for biomedical waste management in dental practices - A pilot project at Thane, India, European Journal of General Dentistry. 235.

Goya, N., Sunil, M. K., Trivedi, A. and Gupta, S. 2016. The Environmental Impact of Dentistry by waste management. International Journal of Oral and Maxillofacial Disease Vol 1. No 2: 8-11.

Haroon Rashid, Zeeshan Sheikh, Fahim Vohra (2015). Allergic Effects Of The Residual Monomer Used In Denture Base Acrylic Resins European Journal Of Dental 20159 (4) : 614-619

Kooviland A, Gholami F, Borujeni (2014). Investigation of The Characteristics and Management of Dental Waste in Urmia, Irac. Journal Mater Cycle Waste Management.

Irhamni, Setiaty Pandia, Edison Purba, Wirsal Hasan (2017). Kandungan Logam Berat pada Air Lindi Tempat Pembuangan Akhir (TPA) Sampah Kota Banda Aceh. Prosiding Seminar Nasional Pascasarjana (SNP) Unsyiah 2017, April 13, 2017, Banda Aceh, Indonesia

Margot Hiltz (2007). The Environment impact of Dentistr. JCDA .www.cda-adc.ca/jcda - Vol. 73, No. 1

Rebecca Allen (2016). The Safe Disposal Of Gypsum Waste Within The Dental Profession. Dental Review News 5 Januari 2016. Manchester United Kingdom.

Sonia B, Yuyun I (2016). Survei awal Pemahaman pada Kelompok Profesi Terhadap Dampak Penggunaan Dental Amalgam di Indonesia .Bali Focus Foundation.
Triadi PT (2011). Pencemaran Logam Berat Merkuri (Hg) Pada Airtanah. Jurnal TEKNIK Vol. 32 No. 1ISSN 0852-1697

Wulandari CY, Sukandar. (2011). Timbulan dan Komposisi Limbah Medis Pelayanan Kesehatan Gigi Umum Perorangan (Studi Kasus Kota Bandung)" 